\title{
Fiks ferdig spesialist?
}

\author{
Alle leger må være nye en gang. Ved organisering i store sykehus er jeg er bekymret for kapasitet og kvalitet \\ i utdanningen av turnusleger. I planleggingen av storsykehuset Innlandet må vi også huske på de yngste legene.
}

«Altså - hvis jeg hadde fått brudd i håndleddet, så ville jeg helst kommet til en ortoped med en gang. At den som dro på plass håndleddet mitt hadde gjort det mer enn ti-tolv ganger tidligere liksom.»

Jeg har hørt liknende ting flere ganger, blant annet fra mer erfarne leger. Noen mener også at turnusleger bør få en mindre rolle på et «storsykehus». Et eksempel jeg har hørt, er å ha mindre turnusleger og flere assistentleger $i$ akuttmottaket for at ting skal gå raskere, bedre og mer effektivt. Jeg vil minne om at én gang alltid må være den forste, og vi må sikre at nettopp det ikke går ut over pasientsikkerheten.

\section{Erfaringsbygging og trygghet}

Kanskje føles det tryggere for en pasient å treffe en lege med mest mulig erfaring med en gang, selv om det er en enkel problemstilling. A ha færre turnusleger er kanskje effektivt for den enkelte avdeling som slipper et «ekstra nivå». Allikevel, om man kalles turnuslege eller ikke, trenger man tid og erfaring for å lære.

Hvor skal man være ny hvis man ikke får erfaring under turnustjenesten? Som assistentlege, med mer ansvar, uten mulighet for tett veiledning? På legevakt, alene?

Tenk deg at du brekker ankelen på fjellet. Det er ikke flyvær, og blodsirkulasjonen er dårlig. Om det skjer meg, vil jeg så klart at legevaktlegen skal dra foten på plass, så godt som mulig, for å redde foten på vei til sykehuset. Jeg har ingen forbehold om at han har gjort det før, men det kan jo være greit at han har sett noen titalls ankler og vet at det bør gjøres noe fort? At han har dratt på plass noe før og tør gjøre det?

\section{Sykehusenes rolle \\ i utdanning av leger}

I Sykehuset Innlandet făr 88 leger hvert år sin mest grunnleggende kliniske erfaring gjennom turnustjenesten. Til sammenlikning utdanner Ahus, med større befolknings- grunnlag, 42 turnusleger i året. Sykehuset Innlandet driver altså dobbelt så effektiv utdanning av fremtidens leger som storsykehuset Ahus, sett i forhold til befolkningsgrunnlaget. Dette er også et «produkt», som jeg ikke vet om dagens markedstenkning innen helsetjenesten verdsetter.

Utdanningskvalitet er vanskeligere å vurdere, men mitt inntrykk er at sykehusene på for eksempel Lillehammer og Gjøvik lar turnusleger tilegne seg erfaring på en trygg måte. Turnuslegene har mye vaktarbeid og variert postarbeid med tett oppfølgning av en mer erfaren lege, som aldri er langt unna. For at opplæring skal prioriteres og holde god kvalitet må det være en integrert og naturlig del av vanlig drift.

På mellomstore sykehus, som på Lillehammer der jeg selv er turnuslege, er det til enhver tid en mer erfaren assistentlege som har oversikt over pasientene som kommer inn på avdelingen. Turnuslegene gjør informasjonsinnhenting og papirarbeid i akuttmottaket og samarbeider med assistentlegen om behandlingsvalg. Assistentlegen har igjen en eller flere spesialister å spørre om hjelp. På denne måten kan den mer erfarne legen få oversikt over flere pasienter enn ellers mulig, og være fristilt fra tidkrevende papirarbeid til oppfølging samtidig som man sikrer opplæring. Jeg synes det virker effektivt.

\section{Store krav i kommunehelsetjenesten} Det er økende kompleksitet og krav over oppgavene i kommunehelsetjenesten. Alle leger i Norge må gjennom turnustjenesten. Samfunnet må bruke det til å sikre alle leger bredt nok erfaringsgrunnlag.

Jeg mener at man skal ha sett flere både dårlige og mindre dårlige pasienter med magesmerter, brystsmerter, forstuinger og brudd før man står der med dem helt alene. Det er nødvendig for å kunne vurdere hastegrad og starte behandling også for alvorlige tilstander om nødvendig.
Mildrid Asgeirsdatter Ullerud mildrid.ullerud@gmail.com Mildrid Asgeirsdatter Ullerud (f. 1986) er utdannet lege i Trondheim og jobber nå som turnuslege i Lillehammer.

PUBLISERT I BLOGGEN

$$
\text { (b) } 10.1 .2014
$$

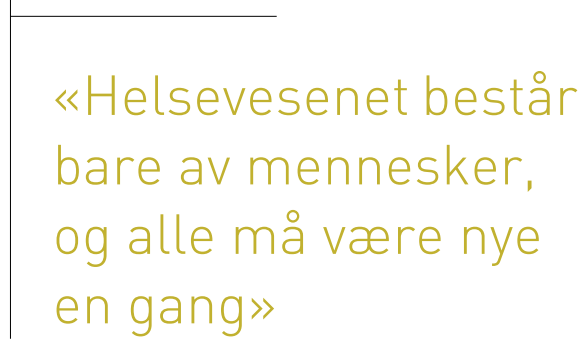

\section{Turnusleger på storsykehus}

I den fremtidige sykehusstrukturen i Innlandet er det snakk om et storsykehus med en liknende dimensjon som Ahus. Hva vil i så fall skje med utdanningskapasiteten? Med økende størrelse - hvor mange turnusleger kan avdelingene klare å veilede på en god måte? Hvordan skal det organiseres?

Sykehusenes funksjon som utdanningsinstitusjoner er også viktig når man skal planlegge fremtidens sykehusstruktur. Utdanning er investering i fremtidens helsevesen, erfarne fastleger og overleger. Det handler om trygghet for både leger og pasienter. Helsevesenet består bare av mennesker, og alle må være nye en gang.

Kommentarer til og diskusjoner om innlegget finner du på blogg.tidsskriftet.no Vil du blogge, ta kontakt. 